\title{
Krokodyl 814 w produkcji wież wiatrowych
}

\section{Crocodile 814 in the wind towers manufacturing}

\section{Streszczenie}

W artykule przedstawiono unikatową technologię oraz urządzenia do montażu i spawania słupów wież wiatrowych. Na przykładzie kompleksowej zautomatyzowanej linii produkcyjnej, w której centrum znajduje się urządzenie Krokodyl 814, omówiono szczegółowo budowę i sposób działania tej aplikacji oraz liczne zalety i korzyści płynące z jej stosowania.

\section{Abstract}

In following text author presents unique technology and equipment for mounting and welding wind towers. Based on example of complex automated production line, where machine called Crocodile 814 plays a major role, author describes in details construction and functionality of this application, showing advantages of this technology.

\section{Wstęp}

Początek XXI w. zaowocował m.in. łatwo dostrzegalną zmianą naszego krajobrazu, gdzie coraz częściej widać piękne, wyniosłe i monumentalne elektrownie wiatrowe, ulokowane zarówno na lądzie, jak i na morzu. Ten widok pozostanie pewnie już na stałe, ponieważ we współczesnym świecie jest potrzebna zmiana sposobu wytwarzania energii elektrycznej z paliw kopalnych na energię ze źródeł odnawialnych.

W większości obecnie budowanych elektrowni wiatrowych jako konstrukcję do zamocowania generatora i łopat wykorzystuje się stalową rurę o stożkowym kształcie, ze średnicą rosnącą ku podstawie, zwaną powszechnie wieżą wiatrowa. Takie rozwiązanie konstrukcyjne gwarantuje dużą wytrzymałość, oszczędność materiału oraz możliwość automatyzacji procesu prefabrykacji segmentów rur w fabryce. Temu ostatniemu zagadnieniu poświęcone jest niniejsze opracowanie.

\section{Słupy wież wiatrowych}

Proces wytwarzania wież wiatrowych składa się z następujących operacji: formatowanie blach i przygotowanie

Mgr inż. Andrzej Nieroba - Cloos Polska. ich krawędzi do spawania, zwijanie blach w kręgi zwane cargami, spawanie wzdłużne blach, składanie ze sobą kolejnych zwijek, ich montaż oraz spawanie obwodowe, wykonanie kołnierzy i wspawanie ich do skrajnych carg sekcji wieży, czyszczenie, malowanie i zabezpieczenie antykorozyjne.

Chociaż każdy z tych etapów jest istotny dla całego przedsięwzięcia i wymaga należytego wykonania, to najistotniejsza jest operacja składania i montażu carg ze sobą, gdyż od właściwego wykonania tego zadania zależy zachowanie osiowości i poprawności kształtu nie tylko poszczególnych sekcji, ale i całej wieży. Bez odpowiednich narzędzi, oprzyrządowania czy systemu montażu składanie ze sobą carg jest zadaniem niesłychanie uciążliwym i wymagającym zaangażowania dużej liczby pracowników. Warto podkreślić, że mamy do czynienia z cargami o średnicach nawet do $6 \mathrm{~m}$, wykonanych $\mathrm{z}$ blachy o grubości dochodzącej do $100 \mathrm{~mm}$. Masa pojedynczej zwijki wynosi ok. kilkanaście ton. Manewrowanie takim elementem jest bardzo trudne, a dwie sąsiednie cargi trzeba ze sobą zestawić ich powierzchniami czołowymi z dużą dokładnością. W tym etapie produkcji słupów wież wiatrowych bardzo pomocne, czy wręcz niezastąpione jest urządzenie o handlowej nazwie Krokodyl 814.

Krokodyl jest opatentowanym urządzeniem niemieckiej firmy Deuma. Jest on znany na rynku od blisko 50 lat. Pierwsze wdrożenia Krokodyla miały miejsce głównie w produkcji korpusów łodzi podwodnych (okres wyścigu zbrojeń), a kolejne lata to czas ciągłej modernizacji. Obecny kierunek rozwoju urządzenia 
Krokodyl 814 oraz liczne jego wdrożenia są efektem systematycznego rozwoju energetyki wiatrowej, a co za tym idzie - poszukiwania przez producentów wież wiatrowych wydajnych systemów produkcyjnych. Niewątpliwie jednym z nich jest linia montażowa spawalnicza Krokodyl 814 postrzegana jako najlepsze rozwiązanie dla tego rodzaju produkcji.

\section{Budowa Krokodyla}

W ogólnym zarysie, jak przedstawiono na rysunku 1, Krokodyl zbudowany jest z połączonych ze sobą dwóch strzemion, wskutek czego budową przypomina spłaszczoną literę C.

Taki kształt Krokodyla jest konieczny, aby po wprowadzeniu go między rolki obrotnika, na którym leży zwijka, mógł objąć ją na całej szerokości między swoje strzemiona. Na końcu górnego i dolnego strzemienia, od otwartej strony urządzenia, rozmieszczone są

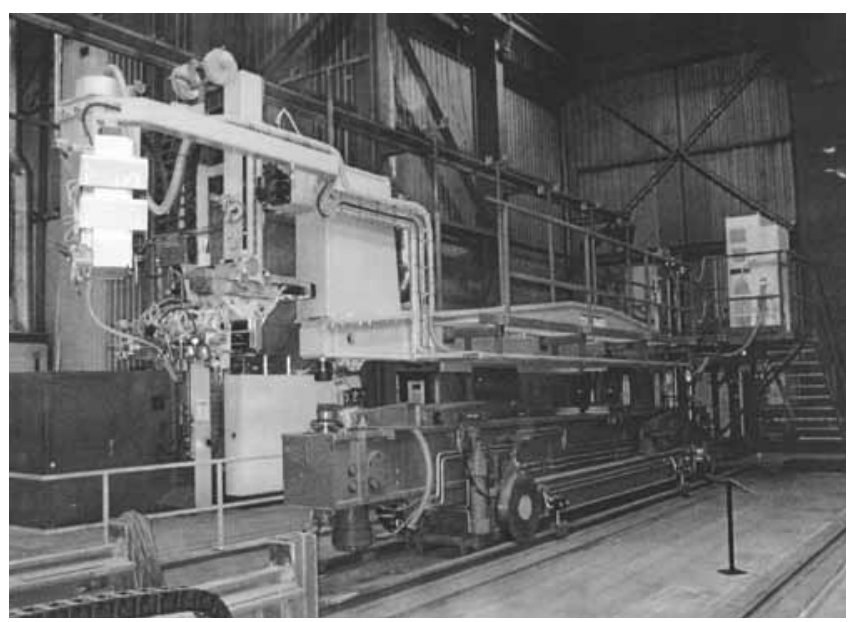

Rys. 1. Urządzenie Krokodyl 814

Fig. 1. Krokodyl 814 installation

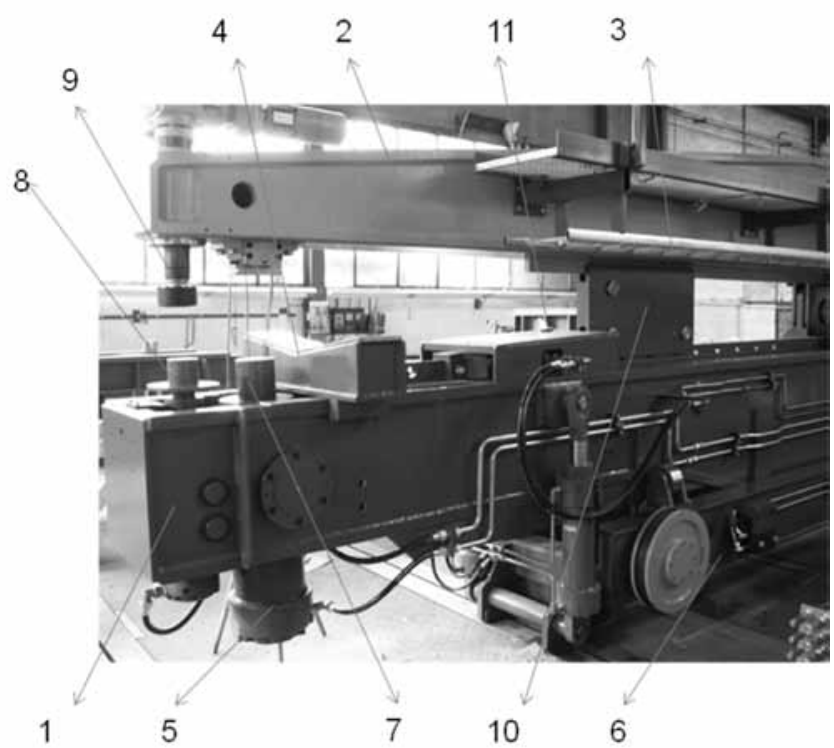

Rys. 2. Elementy systemu centrowania

Fig. 2. Elements of the alignment system elementy systemu centrowania. Całość jest posadowiona na wózku umożliwiającym przemieszczanie się Krokodyla po szynach ze znaczną prędkością i dużą siłą. Strzemiona z wózkiem są połączone w sposób ruchomy, w płaszczyźnie pionowej, poprzez przegub i parę siłowników hydraulicznych umieszczonych od czoła urządzenia. Na górnym strzemieniu jest zabudowana głowica spawalnicza oraz pulpit operatorski. W tylnej części znajdują się silniki, pompy układu hydraulicznego, zasilacze spawalnicze, zasobniki topnika, szpule drutu itp. Wzdłuż górnego strzemienia jest ulokowany podest dla operatora.

Wspomniany obrotnik jest integralną częścią urządzenia, ma prześwit między rolkami o wielkości dopasowanej do dolnego strzemienia Krokodyla. Obrotnik dysponuje dwoma niezależnymi napędami rolkowymi potrzebnymi do swobodnego obracania jedną i drugą cargą w dowolną stronę. Obrotnik ten jest również wyposażony w ruchome rolki i podpory, dzięki którym jest możliwe przemieszczanie cargi w różnych kierunkach. Całość kinematycznego układu Krokodyla wraz z obrotnikiem gwarantuje bardzo szybkie i pewne wzajemne ułożenie montowanych carg, tak aby była zachowana ich osiowość i dokładność styku ich krawędzi na całym obwodzie.

Główne podzespoły systemu mocowania i centrowania carg, przedstawione na rysunku 2, to: 1 i 2 -dolne i górne strzemiona Krokodyla; 3 - platforma serwisowa; 4 - pryzma podporowa; 5 - siłownik hydrauliczny; 6 - wózek; 7 , 8 i 9 - elementy dociskowe; 10 - docisk osiowy; 11 - ruchoma podpora.

\section{Opis działania}

Najistotniejszą cechą charakterystyczną Krokodyla jest system montażu carg schematycznie przedstawiony na rysunku 3.

Przebieg procesu składania i montażu carg wygląda następująco. Pierwszą czynnością po założeniu carg na rolki obrotnika (przy wycofanym Krokodylu) i uprzednim dostosowaniu rozstawu rolek do średnicy zwijki, jest wyszukanie takiego wzajemnego położenia carg, aby ich spoiny wzdłużne się mijały, a ewentualne odchyłki wymiaru średnic były

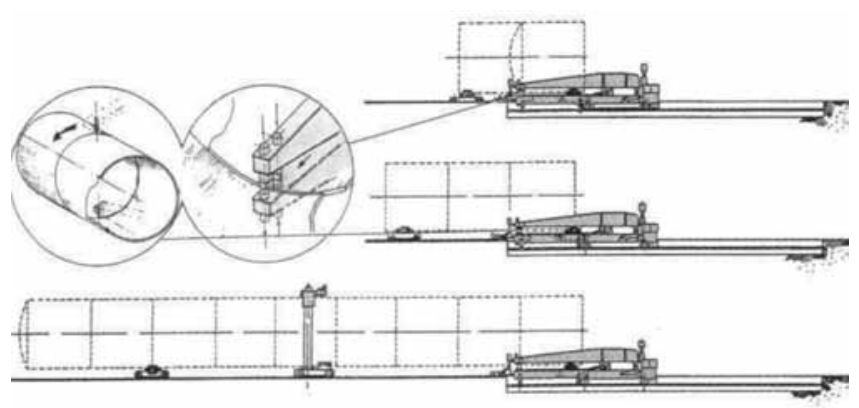

Rys. 3. Schemat budowy sekcji wieży wiatrowej

Fig. 3. Scheme of the wind tower sections 
rozłożone równomiernie na całym obwodzie. $W$ tej pozycji zachowywany jest kilkucentymetrowy odstęp między cargami. Następnie Krokodyl przejeżdża po torowisku w kierunku wykonywanego styku i nasuwa się na ostatnią zwijkę, obejmując całą jej szerokość w przestrzeń między strzemionami. W kolejnym kroku Krokodyl zaciska pierwszą parę siłowników hydraulicznych na przedostatniej zwijce, dzięki czemu zostaje ona (lub większy fragment sekcji) unieruchomiona. Dalej Krokodyl wraz z ruchomą częścią obrotnika dosuwa ostatnią cargę do poprzedniej, dociskając ją z dużą siłą. Następnie zostaje zamknięta druga para siłowników systemu centrowania, przy jednoczesnym uniesieniu końca ostatniej cargi w celu zapobieżenia powstawaniu szczeliny w górnej części styku obwodowego. W razie potrzeby w tej części operacji można manewrować ostatnią cargą w różnych kierunkach, tak aby zapewnić dokładny styk łączonych krawędzi carg, a tym samym osiowość całej sekcji wieży wiatrowej. Następnie wykonywana jest pierwsza spoina sczepna w dolnej części pomiędzy pierwszą a drugą parą siłowników. Po otwarciu zacisków i obrocie całości o $180^{\circ}$ jest wykonywana kolejna spoina sczepna i w analogiczny sposób pozostałe.

Tak przygotowany styk jest gotowy do pospawania od wewnętrznej strony głowicą umieszczoną na końcu górnego strzemienia Krokodyla. Spawanie odbywa się w pozycji podolnej przy nieruchomej głowicy spawalniczej, a ruch roboczy jest realizowany przez obrotnik rolkowy. Ostatnią czynnością jest przepchnięcie całości sekcji do przodu o szerokość jednej zwijki. Operacji tej dokonuje Krokodyl w ten sposób, że wycofuje się do początku sekcji, zaciska parę siłowników na krawędzi ostatniej cargi, podnosi sekcję lekko do góry i w ruchu powrotnym przesuwa całość do przodu, robiąc tym samym miejsce do położenia kolejnej zwijki. Ważną rolę odgrywają obrotniki pomocnicze, które przed rozpoczęciem procesu są umieszczone jeden za drugim w pobliżu obrotnika głównego, aby w miarę jak sekcja rośnie o kolejne cargi, podpierać jej koniec oraz część środkową. Podczas całego procesu montażu i spawania sekcji suwnica jest potrzebna tylko do załadunku zwijek na obrotnik główny Krokodyla. Do wykonywania drzwi serwisowych w dolnej części największej sekcji wieży wiatrowej lub włazów w korpusach łodzi podwodnych można skorzystać z gotowej, zrobotyzowanej aplikacji firmy Cloos. Robot Qirox, pracując naprzemiennie palnikiem plazmowym i MAG, umożliwi precyzyjne wycięcie odpowiedniego otworu oraz wspawanie w to miejsce ościeży drzwi lub włazu.

Powyższy opis ujmuje schematycznie sposób działania Krokodyla. W rzeczywistości poszczególne operacje są bardziej skomplikowane, gdyż współdziałają ze sobą w odpowiednich sekwencjach elementy układu kinematycznego Krokodyla i jego obrotników. W tym opracowaniu nie sposób opisać wszystkich najmniejszych kroków i czynności, tym bardziej że niektóre $z$ nich stanowią tajemnicę producenta.

\section{Krokodyl - główny element linii}

Głównym obszarem zastosowań urządzenia Krokodyl 814, jak wynika z jego budowy, jest produkcja wielkogabarytowych elementów o przekroju kołowym, budowanych z carg, czyli tam gdzie jest konieczność wykonywania spoin obwodowych. Kształt elementu może być cylindryczny lub stożkowy, jak w przypadku wież wiatrowych. Urządzenie to umożliwia również montaż i spawanie kołnierzy oraz wewnętrznych usztywnień np. przy produkcji korpusów łodzi podwodnych. Poza szerokością cargi, która praktycznie wynika z hutniczych formatów blach, jedyną wielkością gabarytową ograniczającą stosowalność tego urządzenia jest minimalna średnica detalu wynosząca $2000 \mathrm{~mm}$. Średnica maksymalna, grubość ścianki, długość spawanego detalu i jego masa są właściwie nieograniczone, zależą tylko od możliwości transportowych danego detalu.

Dobra koniunktura w sektorze energetyki wiatrowej spowodowała dynamiczny rozwój urządzenia Krokodyl 814. Obecnie nie jest on już tylko samodzielnym stanowiskiem montażowym spawalniczym. W większości wdrożeń, w tym u takich potentatów jak np. firma SIF Holand, jest on centralnym i najważniejszym komponentem całościowej, zautomatyzowanej spawalniczej linii montażowyej. Producent oferuje swoim klientom optymalne rozwiązanie całości procesu wytwarzania słupów wież wiatrowych. Podobnie jak Krokodyl pozostałe stanowiska wchodzące w skład linii produkcyjnej wyróżniają się innowacyjnością i zapewniają prowadzenie procesu z maksymalną wydajnością przy zaangażowaniu minimalnej liczby pracowników.

$\mathrm{Na}$ rysunku 4 przedstawiono schemat organizacyjny kompletnej zautomatyzowanej linii montażowej, której głównym elementem jest Krokodyl 814. Ta kompaktowa linia jest przewidziana do średnioseryjnej produkcji, a jej niewielkie wymiary zabudowy na hali produkcyjnej wskazują na kolejny aspekt przemawiający na korzyść omawianego rozwiązania. Dla większych potrzeb produkcyjnych bez trudu, ze względu na pełną skalowalność, można zaprojektować dwa lub cztery równoległe ciągi technologiczne Krokodyl 814. W takim przypadku wskazane będzie ulokowanie całości w długiej prostokątnej hali, tak aby suwnice

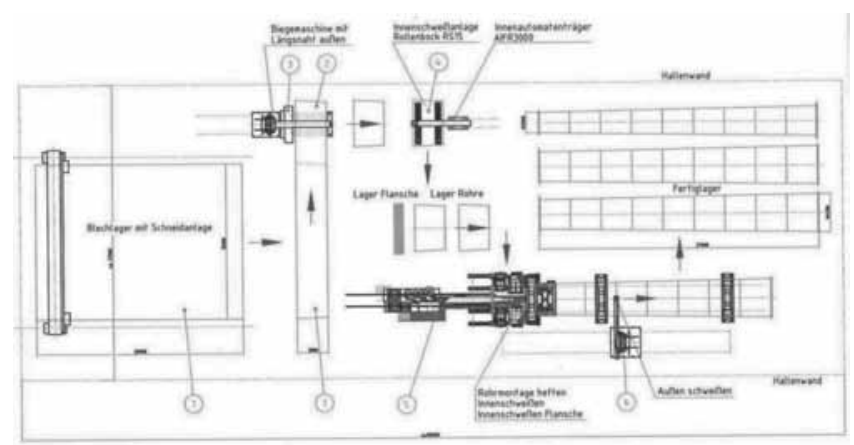

Rys. 4. Schemat organizacyjny linii produkcyjnej wież wiatrowych Fig. 4. Organizational chart of the wind towers production line 
umieszczone na jednym torowisku obsługiwały wszystkie etapy produkcji. Dodatkowym atutem będzie możliwość wykorzystania słupowysięgników, przeznaczonych do spawania zewnętrznych warstw spoin obwodowych, do dwóch sąsiadujących ciągów Krokodyla.

Od właściwego zaprojektowania linii produkcyjnej Krokodyl 814 będzie zależała wydajność, pracochłonność, a więc i końcowy, jednostkowy koszt wytwarzania. Podstawowym kryterium pod tym względem jest oczywiście asortyment produkcji. To od niego zależy liczba potrzebnych ciągów Krokodyla 814, liczba walcarek, słupowysięgników, kabin śrutowniczych i malarskich oraz innych urządzeń pomocniczych. Istotnym czynnikiem będzie również wybór odpowiedniej techniki spawalniczej oraz proces jej realizacji. Tradycyjną technologią jest spawanie łukiem krytym, w odmianie wielodrutowej (układ Tandem bądź Twin). Przy wyborze tej metody spawania, w celu zwiększenia wydajności, wskazane jest przygotowywanie złączy obwodowych na niesymetryczne „X” z mniejszą liczbą ściegów po stronie wewnętrznej cargi. Takie rozwiązanie umożliwi równoczesne wykonywanie jednego ściegu wewnątrz, przez głowicę umieszczoną na Krokodylu, oraz kilku (dwóch, trzech) ściegów zewnętrznych za pomocą słupowysięgników. Parametry spawania muszą być wtedy bardzo ściśle dopasowane, już na etapie projektu, do jednej wspólnej prędkości obwodowej.
Ze względu na duże grubości łączonych blach i sposób przygotowania krawędzi właściwych dla łuku krytego, dobrym rozwiązaniem byłoby zastosowanie metody spawania hybrydowego LASER/MAG, przynajmniej wewnętrznej części łącza. Zaletą tej metody jest możliwość pełnego przetopienia materiału o znacznej grubości, a więc gotowe złącze można uzyskać przy jednym przejściu, a nie przy kilkunastu tak jak w metodzie SAW. Kolejne oszczędności wynikają z braku konieczności ukosowania brzegów spawanych krawędzi. Również kształt spawanego elementu jest korzystny dla technologii spawania laserowego, gdyż rura ogranicza możliwość emisji promieniowania światła laserowego, tak że wystarczy osłonić przednią i tylną część sekcji i spawanie będzie się odbywać w zamkniętej komorze.

Większą wydajność procesu można uzyskać przez zastosowanie wielopalnikowej głowicy spawalniczej z równomiernie rozmieszczonymi palnikami, wraz z wykorzystaniem jednej z wysokowydajnych odmian metody spawania MAG (np. Tandem lub RapidWeld firmy Cloos). Liczba użytych palników będzie determinowała krotność skrócenia czasu wykonania jednego pełnego ściegu spoiny obwodowej. Taką głowicę można zamontować na Krokodylu i za jej pomocą wykonywać wewnętrzną część spoiny. Również i przy takim rozwiązaniu zamknięty kształt rury, jaką jest słup wieży wiatrowej, osłoni światło łuku spawalniczego.

\section{Podsumowanie}

Nie przypadkiem wskazane sąsiadujące ze sobą firmy Deuma i Cloos (miasta Netphen i Haiger) stały się liderami w swoich branżach. Deuma w dziedzinie mechanizacji procesów produkcyjnych oraz Cloos w zrobotyzowanych aplikacjach spawalniczych. Długoletnia współpraca, wymiana doświadczeń oraz fakt, że ich produkty się doskonale uzupełniają, stworzyły wspaniały tandem mogący zaoferować klientom najlepsze rozwiązania automatyzacji i mechanizacji procesów spawania wielkogabarytowych komponentów.

Czy to w wielkoseryjnej produkcji słupów wież wiatrowych, czy w jednostkowym procesie budowy korpusów łodzi podwodnych, opisywane urządzenie Krokodyl 814 gwarantuje prowadzenie montażu i spawania obwodowego carg z najwyższą dokładnością przy najkrótszym czasie potrzebnym do tego zadania. Wart podkreślenia jest fakt, niespotykany w żadnej innej produkcji detali o podobnych gabarytach, że Krokodyla obsługuje tylko jeden pracownik, wykonując wszystkie wyżej opisane czynności montażu i wewnętrznego spawania carg.

Kompleksowa zautomatyzowana spawalnicza linia montażowa, w której centrum znajduje się urządzenie Krokodyl 814, jest najlepszym rozwiązaniem dla producentów konstrukcji takich jak słupy wież wiatrowych.

Artykuł został opublikowany również w numerze 08/2011 Przeglądu Spawalnictwa.

\section{W następnym numerze}

W następnym numerze opublikowane zostaną artykuły prezentowane na XVIII Konferencji Spawalniczej „Spawanie w energetyce” w Jarnołtówku. 